Vol. 6, No. 2, October 2018, pp. 22 25

\title{
Studi Uses And Gratification Tentang Budaya Populer Korea Pada Komunitas BTS Army Indonesia Amino
}

Susanti Dwi Cahyaningrum ${ }^{1}$

${ }^{1}$ Program Studi Ilmu Komunikasi, Universitas Ahmad Dahlan, Indonesia

\begin{tabular}{|c|c|}
\hline Article Info & ABSTRACT \\
\hline Article history: & \multirow{7}{*}{$\begin{array}{l}\text { Penelitian ini bertujuan untuk Mengetahui bagaimana budaya populer Korea } \\
\text { pada Komunitas bts army Indonesia Amino dengan studi Uses and } \\
\text { Gratification. Penelitian ini menggunakan metode penelitian deskriptif } \\
\text { kualitatif dengan teknik analisis data menggunakan teori uses and } \\
\text { gratification. Teknik pengumpulan data pada penelitian ini dilakukan dengan } \\
\text { wawancara, observasi partisipan, dan studi pustaka. Data wawancara diperoleh } \\
\text { dari empat narasumber yang merupakan anggota komunitas BTS ARMY } \\
\text { Indonesia Amino (BAIA). Observasi partisipan peneliti lakukan dengan } \\
\text { bergabung dengan komunitas BTS ARMY Indonesia Amino (BAIA). Hasil } \\
\text { penelitian menunjukkan bahwa keempat narasumber memiliki perbedaan saat } \\
\text { menjadikan budaya populer Korea sebagai kebutuhan baik informasi maupun } \\
\text { hiburan. Hasil dari penelitian ini berupa makna dari sebuah budaya Korea yang } \\
\text { ada pada komunitas bts army indonesia amino dalam pola kehidupan mereka } \\
\text { sehari hari dengan melihat dari sisi kebutuhan kognitif, Kebutuhan efektif, } \\
\text { kebutuhan integrasi, serta pelepasan ketegangan. }\end{array}$} \\
\hline Received Apr 17, 2018 & \\
\hline Accepted Aug 3, 2018 & \\
\hline Keywords: & \\
\hline Uses and Gratification & \\
\hline Budaya Populer Korea & \\
\hline BTS ARMY Indonesia & \\
\hline
\end{tabular}

This is an open access article under the CC BY-SA license.

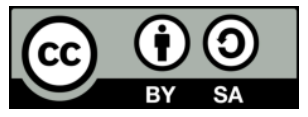

\section{Corresponding Author:}

Susanti Dwi Cahyaningrum,

Program Studi Ilmu Komunikasi, Universitas Ahmad Dahlan,

Email: susanti@comm.uad.ac.id

\section{PENDAHULUAN}

Budaya merupakan suatu kesatuan dari sebuah pengetahuan, kepercayaan, kesenian, hukum, adat istiadat, dan hal-hal lain yang merupakan hasil pemikiran dan pengalaman manusia. Adanya kesempatan suatu budaya untuk berkembang, maka budaya akan melahirkan suatu budaya baru dengan berbagai macam karakteristik yang berbeda. Salah satu faktor pemicu berkembangnya budaya adalah globalisasi (Keesing, 2014) .

Globalisasi adalah proses meluasnya hubungan sosial yang mengakibatkan terjalinnya suatu hubungan antarmanusia di dunia tanpa ada batasan tertentu. Dengan globalisasi, budaya suatu negara akan mudah tersebar hingga dikenal dan dipahami oleh negara lain. Salah satu dampak globalisasi dalam bidang budaya yaitu munculnya istilah Korean Wave (Ardia, 2014).

Korean Wave atau Hallyu atau budaya populer Korea merupakan istilah yang diberikan kepada persebaran budaya Korea yang meluas hingga seluruh dunia. Dari film, drama, musik, fashion hingga makanan Korea sudah menyebar ke negara-negara Asia maupun Barat. Seperti halnya kemunculan boy group dan girl group Korea seperti SNSD, Big Bang, Super Junior, hingga BTS mampu menarik minat berbagai kalangan masyarakat. Dari sinilah penggemar masing-masing boy group dan girl groupakan membentuk suatu komunitas. Salah satu contoh komunitas penggemar boy group Korea di Indonesia adalah BAIA ("DAMPAK PENGARUH GLOBALISASI BAGI KEHIDUPAN BANGSA INDONESIA,” 2017).

BTS ARMY Indonesia Amino (BAIA) merupakan suatu komunitas ARMY, penggemar BTS, salah satu boy groupKorea yang berbasis aplikasi Amino. Aplikasi Amino merupakan aplikasi yang di dalamnya berisi komunitas berjaringan dimana kita bisa menemukan dan bergabung ke komunitas yang kita suka. Berbeda dengan komunitas lainnya yang masih berada dalam satu aplikasi besar yaitu Amino, BTS ARMY Indonesia 
Amino (BAIA) sudah memiliki aplikasi terpisah (standalone app) yang ditawarkan oleh team Amino (Effendy, 2003).

BTS ARMY Indonesia Amino (BAIA) merupakan wadah bagi para ARMY di Indonesia untuk saling berinteraksi. Komunitas ini didirikan pada tanggal 25 September 2016 oleh Shifra Lushka yang merupakan leader sekaligus creator komunitas BTS ARMY Indonesia Amino (BAIA). Hingga bulan November 2019 ini BAIA sudah memiliki lebih dari 87.500anggota.

Setelah setahun berdiri, komunitas ini menjalin kerja sama dengan organisasi Into The Light Indonesia untuk memberikan informasi-informasi tentang suicidal preventing for young people. Kerja sama ini terjalin karena terinspirasi dengan misi idola mereka, BTS, yang sedang melakukan kampanye tentang "Love Myself" dengan UNICEF. Melihat hal tersebut, komunitas BTS ARMY Indonesia Amino (BAIA) akhirnya menjalin kerja sama dan mengadakan projek dengan nama "Love Myself Movement". Tidak hanya menaruh perhatian terhadap idola mereka, anggota komunitas BTS ARMY Indonesia Amino (BAIA) juga sering melakukan diskusi seputar masalah sosial, ekonomi, budaya dan lain sebagainya. Dalam hal ini anggota komunitas BTS ARMY Indonesia Amino (BAIA) tentu saja memiliki perbedaan dalam pengonsumsian akan budaya populer Korea sebagai suatu hal yang mereka sukai. Melihat hal ini, peneliti memutuskan untuk mengambil penelitian tentang bagaimana anggota komunitas BTS ARMY Indonesia Amino (BAIA) mengonsumsi budaya populer Korea sebagai salah satu sumber informasi dan hiburan dalam kehidupan sehari-hari mereka (Ridaryanthi, 2014).

\section{METODE}

Jenis penelitian yang peneliti gunakan yaitu penelitian deskriptif kualitatif.Data yang digunakan dalam penelitian ini terdapat dua jenis data yaitu data primer yang didapat dari wawancara langsung dengan narasumber dan data sekunder yang berasal observasi-partisipan peneliti. Teknik analisis yang digunakan peneliti dalam penelitian ini adalah analisis menggunakan teori uses and gratification (Sugiyono, 2015).

Teknik validasi data yang peneliti gunakan adalah teknik triangulasi. Teknik triangulasi merupakan teknik pemeriksaan keabsahan data yang memanfaatkan sesuatu yang lain diluar data yang terkumpul untuk keperluan pengecekan atau sebagai pembanding terhadap data-data tersebut. Dalam penelitian ini, peneliti menggunakan triangulasi teknik. Triangulasi teknik adalah teknik pengumpulan data yang berbeda-beda untuk mendapatkan data dari sumber yang sama.

\section{HASIL DAN PEMBAHASAN}

Dari hasil wawancara narasumber, keempat narasumber penelitian ini mengenal budaya populer Korea lewat teman atau media. Seperti Dewi dan Buna yang mengenal budaya populer Korea lewat drama yang sempat ditayangkan di stasiun televisi Indonesia. Sedangkan Risca dan Wulan mengaku mengenal budaya populer Korea dari teman sekolah, dimana mereka berada pada lingkungan pertemanan yang sebagian besar sudah suka dengan budaya populer Korea.

Sejak mengenal budaya populer Korea, keempat narasumber mulai tertarik untuk tahu lebih banyak tentang budaya populer Korea. Hal ini menjadikan keempat narasumber peneliti mulai mencari informasi seputar budaya populer Korea dan menjadikannya salah satu kebutuhan dalam kehidupan sehari-hari. Lewat budaya populer Korea, narasumber juga mengaku banyak mengenal orang-orang baru yang biasanya mereka berkumpul dalam sebuah komunitas tertentu.

Kognitif

Kebutuhan kognitif merupakan kebutuhan yang berkaitan dengan peneguhan informasi, pengetahuan, dan pemahaman mengenai lingkungan.Kebutuhan ini didasarkan pada hasrat untuk memahami dan menguasai lingkungan, juga memuaskan rasa penasarandan dorongan untuk penyelidikan individu.

Dengan mengenal budaya populer Korea, keempat narasumber mulai tertarik dengan apa yang ditawarkan oleh budaya populer Korea. Hal ini menjadikan keempat narasumber mencoba untuk mencari informasiinformasi seputar budaya populer Korea yang mereka suka. Faktor pertemanan yang sama-sama menyukai budaya populer Korea juga menjadikan keempat narasumber secara tidak langsung mengetahui informasi seputar budaya populer Korea.

Afektif

Kebutuhan afektif merupakan kebutuhan yang berkaitan dengan peneguhan pengalaman-pengalaman yang estetis, menyenangkan, dan emosional.Dewi dan Risca mengaku dengan mengenal budaya populer Korea membuat mereka merasa senang. Hal ini dikarenakan perbedaan tayangan yang disajikan oleh budaya populer Korea dan Indonesia berbeda. Hanya dengan menonton tayangan-tayangan dari Korea sudah mampu membuat mereka bahagia.

Integrasi Personal

Kebutuhan yang berkaitan dengan peneguhan kredibilas, kepercayaan, stabilitas, dan status individual.Dari 
keempat narasumber, ada tiga orang yang merasa dengan mengonsumsi budaya populer Korea bisa menambahkan rasa percaya diri mereka. Dewi, Buna, dan Wulan mengaku lewat produk budaya populer Korea yaitu KPOP mampu membuat mereka merasa percaya diri. Hal ini dikarenakan meraka menerima pesan yang disampaikan oleh salah satu boy group Korea yang sering menyampaikan pesan untuk mencintai diri sendiri yang akhirnya memberikan dampak positif kepada ketiga narasumber ini.

Integrasi Sosial

Integrasi sosial merupakan kebutuhan yang berkaitan dengan peneguhan kontak dengan keluarga, teman, dan dunia.Hal tersebut didasarkan pada hasrat untuk berafiliasi.Hasrat untuk berafiliasi atau berhubungan dengan orang menjadi kebutuhan setiap manusia. Dalam konteks budaya populer Korea, menjalin hubungan dengan orang lain terlihat dengan adanya penggemar. Penggemar-penggemar budaya populer Korea cenderung untuk mencari teman yang memiliki ketertarikan dengan hal yang sama. Dalam penelitian ini berdirinya komunitas BTS ARMY Indonesia Amino (BAIA) menjadi salah satu wadah dimana keempat narasumber menjalin hubungan dengan sesama penggemar BTS di Indonesia.

Pelepasan Ketegangan

Pelepasan ketegangan merupakan kebutuhan yang berkaitan dengan upaya menghindarkan tekanan, ketegangan, dan hasrat akan keanekaragaman.Dalam hal ini pelepasan ketegangan bisa dimaksudkan dengan pengalihan atau pelarian dari kehidupan sehari-hari.Buna, Risca, dan Wulan mengaku dengan mengonsumsi budaya populer Korea bisa membantu mereka melepas ketegangan dari kehidupan nyata mereka. Hiburan yang disajikan bisa membantu mereka untuk melepaskan beban yang biasa didapatkan di kehidupan sebari-hari

\section{KESIMPULAN}

Berdasarkan hasil yang telah disampaikan pada bab sebelumnya, terdapat perbedaan dan persamaan motif yang mendorong masing-masing anggota komunitas BTS ARMY Indonesia Amino (BAIA) dalam mengonsumsi budaya populer Korea. Berdasarkan klasifikasi Elihu Katz tentang motif penggunaan media yang dilakukan oleh keempat narasumber menunjukkan hasil yang berbeda-beda sebagai berikut : (1) Kebutuhan kognitif yang didasarkan pada hasrat untuk memahami, menguasai lingkungan dan memuaskan rasa penasaran individu. Kebutuhan ini terlihat ada pada keempat narasumber dimana mereka mencoba untuk mencari informasi tentang budaya populer Korea sebagai salah satu cara untuk memenuhi kebutuhan. (2) Kebutuhan afektif terkait dengan hal-hal yang menyenangkan yang emosional dan estetis. Kebutuhan ini hanya terlihat pada dua narasumber yaitu Dewi dan Risca. Dewi dan Risca menggunakan budaya populer Korea sebagai salah satu sumber kesenangan yang mampu membuat mereka senang.

(3) Kebutuhan integrasi personal merupakan kebutuhan yang berkaitan dengan kredibilitas dan kepercayaan diri. Ketiga narasumber peneliti yaitu Dewi, Buna, dan Wulan merasa bahwa lewat budaya populer Korea rasa percaya diri mereka meningkat. Hal ini merupakan salah satu dampak yang dihasilkan atas nilai-nilai yang mereka dapat dari budaya populer Korea. (4) Kebutuhan integrasi sosial terkait dengan hubungan keluarga, teman, dan dunia. Kebutuhan ini dimiliki oleh keempat narasumber yaitu Dewi, Buna, Risca, dan Wulan dimana dengan hobi mereka terkait budaya populer Korea mendorong mereka untuk menjalin hubungan dengan sesama penggemar budaya populer Korea. (5) Pelepasan ketegangan terkait dengan usaha untuk menghindar seperti pengalihan atau pelarian diri dari kehidupan sehari-hari. Ketiga narasumber yaitu Dewi, Buna, dan Risca dengan rutinitas yang dijalani dala kesehariannya menggunakan budaya populer Korea sebagai salah satu bentuk pelarian diri. 


\section{REFERENSI}

Ardia, V. (2014). Drama korea dan Budaya Popular. Jurnal Komunikasi.

Collard, J. S. (1979). FANS. In South African mechanical engineer.

DAMPAK PENGARUH GLOBALISASI BAGI KEHIDUPAN BANGSA INDONESIA. (2017). Jurnal Pesona Dasar.

Effendy, O. U. (2003). Ilmu, Teori dan Filsafat Komunikasi. In Citra Aditya.

Katz, E., Blumler, J. G., \& Gurevitch, M. (1973). Uses and Gratifications Research. Public Opinion Quarterly. https://doi.org/10.1086/268109

Keesing, R. (2014). Teori-Teori Tentang Budaya. Antropologi Indonesia. https://doi.org/10.7454/ai.v0i52.3313

Ridaryanthi, M. (2014). Bentuk Budaya Populer dan Konstruksi perilaku Konsumen ... Pop Culture. https://doi.org/https://media.neliti.com/media/publications/142786-ID-bentuk-budaya-populer-dankonstruksi-per.pdf

Sugiyono. (2015). Metode Penelitian. Metode Penelitian. 